\title{
Effects of cyclamate and food restriction on various metabolites in the rat
}

\author{
By L. PROSKY AND R. G. O'DELL \\ Division of Nutrition, Food and Drug Administration, US Department of \\ Health, Education, and Welfare, Washington, DC 20204, USA
}

(Received 21 April 1971 - Accepted 27 August 1971)

\begin{abstract}
I. Rats were given stock chow diets containing several levels of calcium cyclamate to study the effects on growth and on some metabolites in liver and blood.

2. Levels up to $1 \%$ in the diet produced diarrhoea without affecting body-weight. At a level of $3 \%$ in the diet, body-weight was decreased by $12 \%$ in 8 weeks.

3. No changes were noted in liver protein, lipid and RNA-P and serum protein and lipid. ${ }^{14} \mathrm{CO}_{2}$ excretion during the $\mathrm{x}$ st hour after $\left[{ }^{14} \mathrm{C}\right]$ glucose administration also temained unchanged.

4. Adult rats weighing $500 \mathrm{~g}$ were given, at a restricted intake, a diet with variations in its fat and cyclamate contents.

5. During I 5 weeks, the animals given the fat-supplemented diet plus cyclamate lost twice as much weight as controls without cyclamate and also excreted $20 \%$ more ${ }^{14} \mathrm{CO}_{2}$. When the food intake was further restricted for 15 weeks weight losses in all groups were the same.

6. Serum lipid and free cholesterol concentrations were lowered in the cyclamate group. ${ }^{14} \mathrm{CO}_{2}$ excretion for this group was $35 \%$ higher than for controls, indicating increased metabolic activity.

7. Concentrations of aspartate, glutamate, lactate, succinate, malate and glycerol-Iphosphate in liver were within normal limits. There were indications of decreased levels of lactate and succinate in cyclamate-fed rats which could be associated with aerobiosis and increased metabolic activity.
\end{abstract}

Until recently, the consumption of artificial sweeteners had increased sharply, mainly through their introduction into beverages and food products. These compounds, which were originally marketed for use by diabetics, were reaching nearly $75 \%$ of the population in the United States (Rubini, 1969) at the time cyclamate was withdrawn from the over-the-counter market. At that time their use was still permitted in special food preparations for diabetics or the obese. For the latter, the nonnutritive sweeteners were generally used in combination with food restriction, adding further complications to the metabolic picture. Although the cyclamates are no longer permitted in foods in the United States their effects on metabolic pathways are still of interest.

Fitzhugh, Nelson \& Frawley (195I) fed rats on diets containing sodium cyclamate for a 2-year period. Dietary levels of $1 \%$ or less of the artificial sweetener had little effect. At the $5 \%$ level the rats developed moderate diarrhoea, an effect of cyclamates which has since been described in detail (Hwang, 1966; Schoenberger, Rix, Sakamoto, Taylor \& Kark, I953; Taylor, Richards, Wiegand \& Weinberg, I968). Gross and microscopical findings were consistent with mild inanition.

Distribution studies using ${ }^{35} \mathrm{~S}-$ and ${ }^{14} \mathrm{C}$-labelled cyclamates (Schoenberger et al. 1953; Taylor, Richards \& Davin, 1951 ; Miller, Crawford, Sonders \& Cardinal, I 966) indicated that the sweetener is rapidly and nearly quantitatively excreted in the urine and faeces as unchanged cyclamate. More recent studies with rats have indicated that 
cyclamates may cause growth inhibition, which may be associated with an increase in metabolic rate and interference with cellular nutrient utilization (Nees \& Derse, 1965 , r 967 ). In contrast, Dalderup \& Visser (I969) reported that small amounts of dietary cyclamate stimulated appetite with a concomitant increase in body-weight, which could be attributed to increased efficiency of food conversion. These findings, along with the report of inhibition of induction of tryptophan oxygenase when cyclamate was administered by intubation to healthy rats (Sabri, Sharma \& Krishna Murti, 1969), prompted us to investigate further the effect of cyclamate on some of the intermediary pathways of energy production in the rat.

\section{EXPERIMENTAL}

Animals and diets

Male rats of the Holtzman strain ( $100 \mathrm{~g}$ ) were separated into eleven groups of eight to sixteen animals each. The rats were given a diet of commercial chow (Ralston Purina Co, St Louis, Missouri) supplemented with $0,0 \cdot 1,0 \cdot 2,0.5,1,2,3$ or $4 \%$ of calcium cyclamate (Matheson, Coleman and Bell, East Rutherford, New Jersey). The effects of calcium in the diet were checked by giving three groups of rats the chow diet supplemented with $\mathrm{CaCl}_{2}$ at $\mathrm{Ca}$ levels equivalent to $\mathrm{I}, 2$, or $4 \%$ calcium cyclamate. The rats were housed in individual cages and water and feed were provided ad lib. At the end of the 8-week experimental period the rats were given an intraperitoneal injection of between 5 and $40 \mu \mathrm{Ci}$ D-[U_-14 C]glucose (specific activity $200 \mu \mathrm{Ci} / \mu \mathrm{mol}$ ) and were placed in metabolic cages.

\section{Measurement of radioactivity and biochemical metabolites}

Expired ${ }^{14} \mathrm{CO}_{2}$ was collected in $3 \mathrm{M}-\mathrm{NaOH}$ for $\mathrm{I} h$ after administration of glucose. A sample of the $\mathrm{NaOH}$ was suspended in Cab-O-Sil (Packard Instrument Co., Downers Grove, Illinois) and counted in a liquid scintillation spectrometer. At the end of the collection period, blood was withdrawn by cardiac puncture for serum lipid and protein determinations, and the livers were quickly excised and frozen in Freon for determination of RNA and DNA (Prosky, Roberts, O'Dell \& Imblum, I968), phosphate (Lowry, Roberts, Leiner, Wu \& Farr, 1954) and protein (Lowry, Rosebrough, Farr \& Randall, I95I). Lipid was determined gravimetrically after extraction with ethanol and diethyl ether using a modified Soxhlet tube.

\section{Food restriction study}

In a subsequent experiment, food was restricted to help correlate biochemical changes associated with weight loss and dietary cyclamate. Two groups of twenty-four weanling rats were given commercial chow or chow supplemented with $5 \%$ fat (equal quantities of maize oil and lard) ad lib. for 17 weeks. Seven rats from each group (of approximately $500 \mathrm{~g}$ body-weight) were removed from the experiment and the analyses described above were performed. Total cholesterol and cholesterol esters in serum were determined by the method of Bloor, Pelkan \& Allan (1922). Each group of rats was then divided into an experimental group receiving the same chow supplemented 
with calcium cyclamate $(3 \%)$ and a control group receiving the chow supplemented with calcium lactate ( $\mathrm{Ca}$ equivalent to $3 \%$ calcium cyclamate). Food intake was restricted to $\mathrm{I} 7 \mathrm{~g} /$ rat per $\mathrm{d}$ for the diets of normal fat content and $\mathrm{r} 5 \mathrm{~g} /$ rat per $\mathrm{d}$ for the fat-supplemented diets. After a 15 -week feeding period, three animals were removed from each group for evaluation as previously described. The remainder of the rats in each group continued on the same dietary regimens but food intake was further restricted to $\mathrm{I}_{5}$ and $\mathrm{I}_{3} \mathrm{~g} / \mathrm{rat}$ per $\mathrm{d}$, respectively, for an additional $\mathrm{I}_{5}$ weeks.

\section{Additional analytical techniques}

In addition to the previously described biochemical measurements, liver extracts were prepared for determination of glucose, glycogen and some Krebs cycle intermediates (Busch, Hurlbert \& Potter, 1952). The liver was removed from the rat, frozen in Freon, cut into small sections and homogenized in the frozen state in I' 3 volumes of $0.6 \mathrm{M}$-perchloric acid. The homogenate was centrifuged in the cold and the resulting precipitate was washed twice with 2 volumes of $0.3 \mathrm{M}$-perchloric acid and centrifuged. The supernatant fractions were combined. Perchloric acid was removed from the extract by neutralizing the solution with $2 \mathrm{M}-\mathrm{KOH}$. The supernatant fraction above the insoluble potassium perchlorate salt was removed and taken to dryness in a flash evaporator at $37^{\circ}$. The residue was dissolved in $\mathrm{xo} \mathrm{ml}$ of distilled water and added to a $0.9 \times 33 \mathrm{~cm}$ column containing Dowex-I-formate $\times 8,200-400$ mesh, and the resin was washed with distilled water until $100 \mathrm{ml}$ of eluate had been collected. The eluate was analysed for glucose and glycogen by the method of Seifter, Dayton, Novic \& Muntwyler (1950). The column was then eluted with a gradient approaching $6 \mathrm{M}$-formic acid. The three-chambered Autograd (Technicon Instruments Corp., Tarrytown, New York) contained $100 \mathrm{ml}$ water in both the exit and central chambers and $100 \mathrm{ml} 6 \mathrm{M}$-formic acid in the third chamber. This gradient was followed by an additional $100 \mathrm{ml}$ of $6 \mathrm{M}$-formic acid and $100 \mathrm{ml}$ of $\mathrm{M}$-ammonium formate to elute hexose and nucleoside diphosphates and triphosphates. Fractions of $2 \mathrm{ml}$ each were collected at a rate of 12 drops/min. Radioactivity in the effluent was monitored either by removing portions of $100 \mu \mathrm{l}$ for counting in Bray's solution (Bray, I960) in a liquid scintillation spectrometer or by passing the effluent through an anthracene-containing flow cell located in the well of a liquid scintillation spectrometer. The contents of the tubes containing the individual peaks were taken to dryness under reduced pressure; the fractions were then combined in a small volume of water and neutralized before assay. If further separation was required the fractions were re-chromatographed. Lactate fractions were flash-evaporated to dryness, teconstituted to an appropriate volume with water and neutralized before assay. Lactate, aspartate, glutamate, malate, and glycerol-r-phosphate were determined by enzymic methods (Bergmeyer, 1965). Succinate was assayed using a crude succinate dehydrogenase preparation from rat liver (Clark \& Porteous, 1964 ). Citrate was assayed by the colorimetric method of Schneider, Striebich \& Hogeboom (I956). 
RESULTS

First study

The effects on body-weight of chow diets supplemented with various amounts of calcium cyclamate are shown in Fig. I. Groups of rats that ate diets supplemented with cyclamate at levels ranging from 0.1 to $2 \%$ exhibited no differences in bodyweight (not shown) from the controls. Body-weight was depressed by $12 \%$ when the cyclamate content of the diet was $3 \%$, but no greater depression was noted at a level of $4 \%$. Chronic softening of the stools and slight diarrhoea were observed in rats given

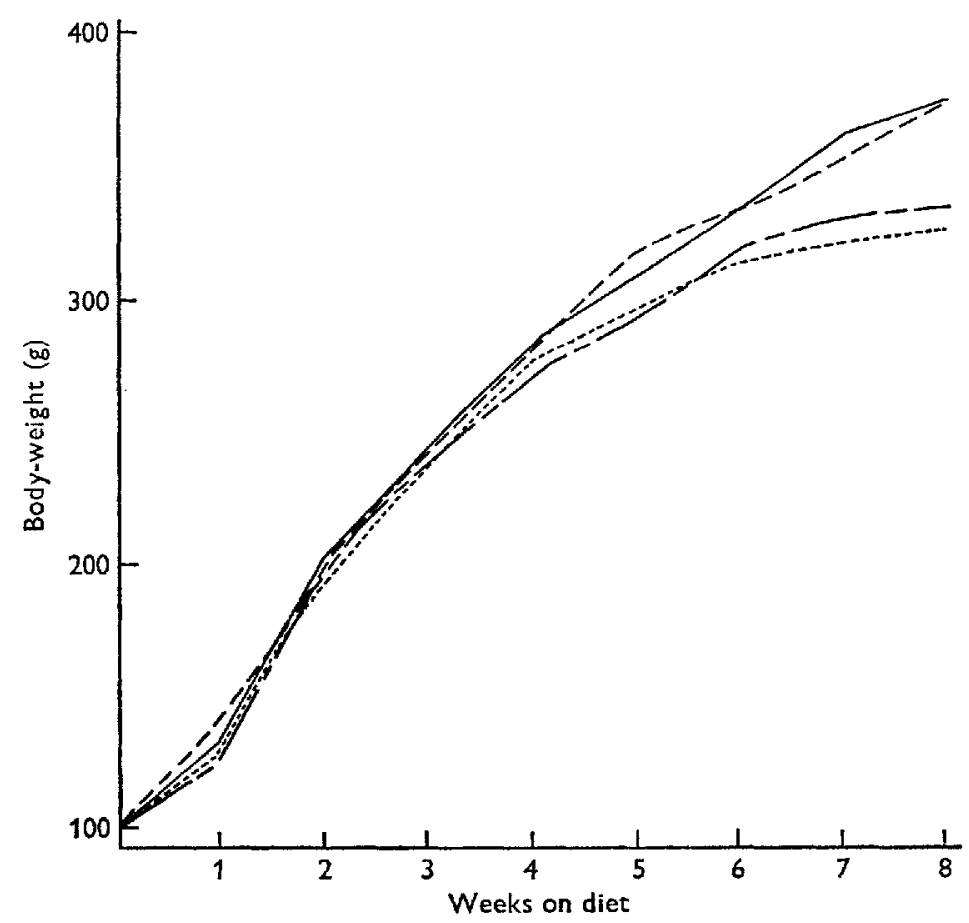

Fig. I. Mean body-weight of groups of eight to sixteen rats given a chow diet alone or supplemented with calcium lactate or calcium cyclamate, - , controls;,$--+\mathrm{CaCl}_{2} ;-.--,+3 \%$ cyclamate;,$---+4 \%$ cyclamate.

cyclamate at levels greater than $\mathrm{r} \%$ of the diet. No changes were observed between groups in liver concentrations of lipid, protein, RNA-P and DNA-P, or serum concentration of lipid and protein, or in ${ }^{14} \mathrm{CO}_{2}$ expired when rats were given an intraperitoneal injection of $\left[{ }^{14} \mathrm{C}\right]$ glucose (Table $\mathrm{I}$ ).

\section{Second study}

Growth phase. Although no significant differences were noted (Table 2), there was a trend toward fat accumulation in the liver and serum of rats given the fat-supplemented diets; the average values increased by 8.5 and $4.5 \%$ respectively. Concentrations of total cholesterol and cholesterol esters were increased by I I and $25 \%$. These 
Vol. 27 Effects of cyclamate on metabolism

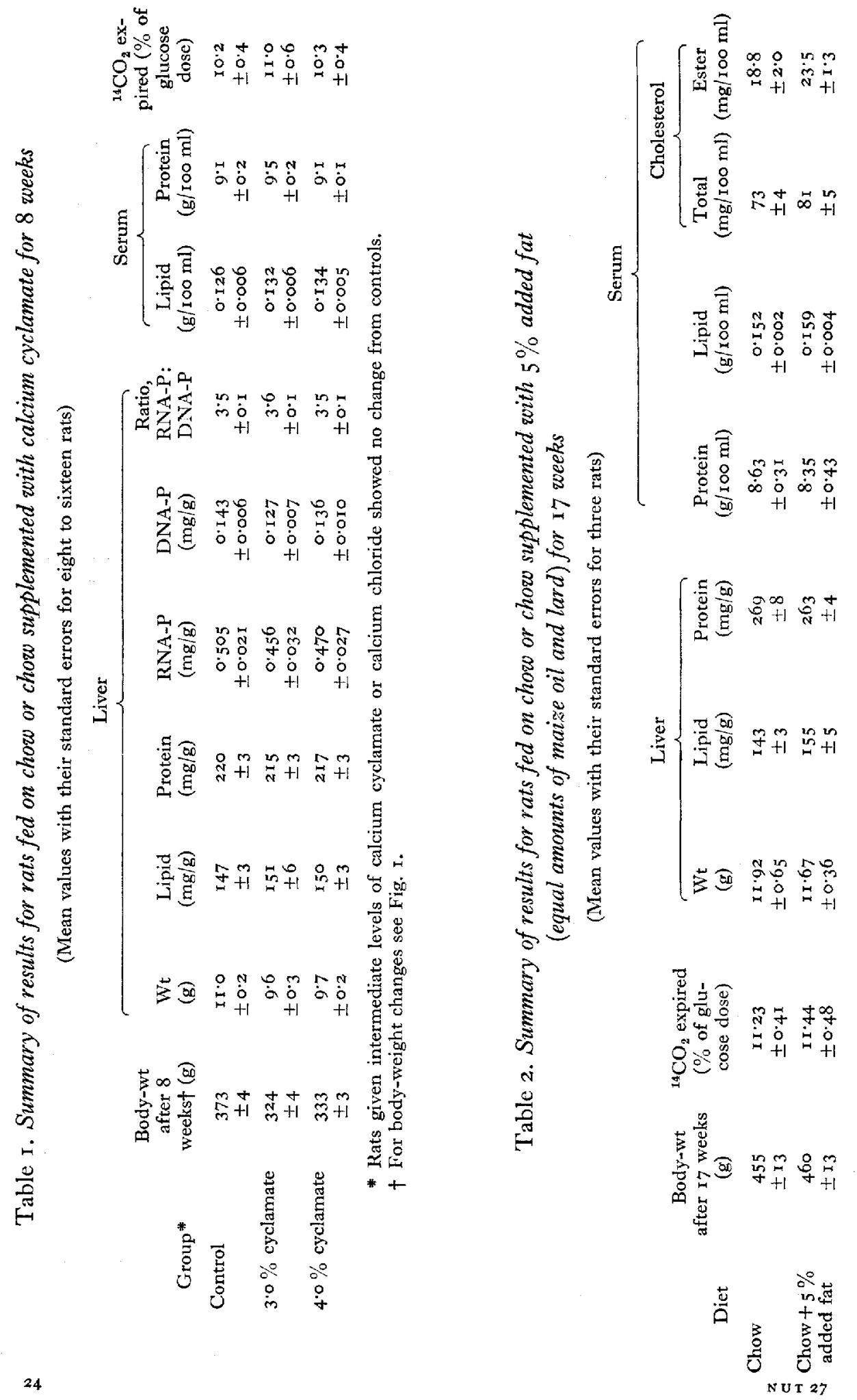


results, which can be attributed to the increased dietary fat, served as base-line values for the weight-reduction aspects of the study.

Food-restriction phase. The results of food restriction accompanied by variations of amounts of fat and cyclamate in the diet for a 15 -week period are shown in Table 3. The most pronounced effect was observed in the group of rats given cyclamate in combination with the fat-supplemented diet; this group lost approximately twice as much weight as their controls $(P<0.005)$. Addition of cyclamate in the normal chow diet had no effect. Production of ${ }^{14} \mathrm{CO}_{2}$ from animals given [ ${ }^{14} \mathrm{C}$ ]glucose was depressed by $25 \%$ when fat was added to the diet. Addition of cyclamate to the fat-supplemented diet increased ${ }^{14} \mathrm{CO}_{2}$ excretion by $20 \%(P<0.05)$. This increase was also observed when ${ }^{14} \mathrm{CO}_{2}$ excretion was expressed on a liver-weight basis.

Table 3. Body-weight loss and expired ${ }^{14} \mathrm{CO}_{2}$ of rats given a restricted diet of chow + calcium lactate or chow + calcium cyclamate with and without added fat for 15 weeks

(Mean values with their standard errors for three rats)

\begin{tabular}{|c|c|c|c|}
\hline \multirow[b]{2}{*}{ Dietary addition } & \multirow[b]{2}{*}{$\begin{array}{c}\text { Body-wt loss } \\
\text { (g) }\end{array}$} & \multicolumn{2}{|c|}{${ }^{14} \mathrm{CO}_{2}$ expired } \\
\hline & & $\begin{array}{l}\% \text { of }{ }^{14} \mathrm{C} \text { in } \\
\text { glucose dose }\end{array}$ & $\begin{array}{l}\text { Relative to liver wt } \\
\text { (counts } / \mathrm{min} \\
\times 10^{5} \text { per g) }\end{array}$ \\
\hline Lactate & $\begin{array}{r}55 \\
\pm 8\end{array}$ & $\begin{array}{r}22.5 \\
+2.9\end{array}$ & $\begin{array}{r}1.23 \\
\pm 0.10\end{array}$ \\
\hline $3 \%$ Cyclamate & $\begin{array}{r}60 \\
\pm 8\end{array}$ & $\begin{array}{r}25 \cdot 7 \\
\pm 2 \cdot 0\end{array}$ & $\begin{array}{r}1.53 \\
\pm 0.16\end{array}$ \\
\hline Lactate $+5 \%$ added fat & $\begin{array}{r}52 \\
\pm 6\end{array}$ & $\begin{array}{r}16 \cdot 2 \\
\pm 1 \cdot 3\end{array}$ & $\begin{array}{r}0.92 \\
\pm 0.12\end{array}$ \\
\hline $3 \%$ Cyclamate $+5 \%$ added fat & $\begin{array}{r}99 \\
\pm 14\end{array}$ & $\begin{array}{r}20 \cdot 2 \\
\pm I \cdot I\end{array}$ & $\begin{array}{r}1.29 \\
\pm 0.08\end{array}$ \\
\hline
\end{tabular}

The results of further restricting the same diets for an additional ${ }_{5}$ weeks are shown in Tables 4,5 and 6 . This 30 -week period of food restriction resulted in equal weight loss in all groups. Liver weights of rats receiving the fat-supplemented diets with cyclamate were depressed significantly $(P<0.005)$ and were also less when calculated on a body-weight basis. Serum lipid and total cholesterol concentrations of the rats given fat plus cyclamate were 13 and $17 \%$, respectively, less than those of controls without cyclamate $(P<0.005)$. The excretion of ${ }^{14} \mathrm{CO}_{2}($ Table 5) was increased by $35 \%$ when cyclamate was added to the fat-supplemented $\operatorname{diet}(P<0.005)$. This increase is significant when the expiration relative to body-weight or liver weight is considered. No changes were observed in the glucose or glycogen content of liver (Table 5).

\section{Chromatography and assay of extracts}

A typical radiochromatogram of a separation of some known metabolic compounds is shown in Fig. 2. Fig. 3 illustrates a separation of these compounds in an extract of liver from a rat given a diet containing fat plus cyclamate. Results of the chemical determinations of these metabolic intermediates in the liver are shown in Table 6. 
Vol. 27

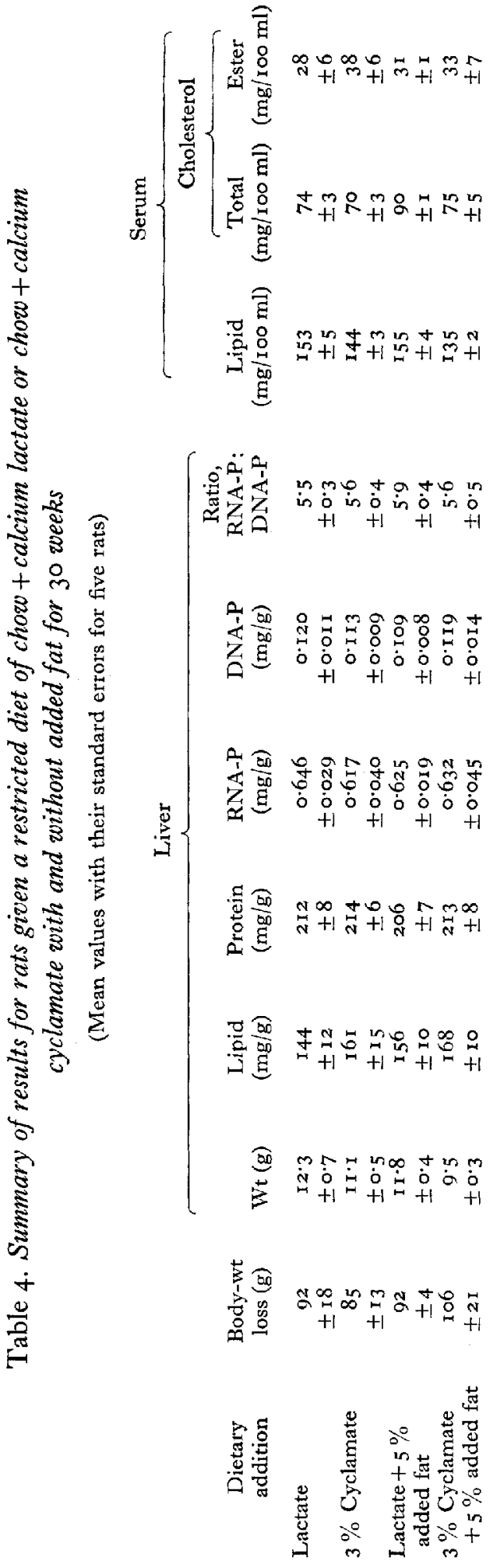


Table 5. Glucose and glycogen concentrations in liver and expired ${ }^{14} \mathrm{CO}_{2}$ in rats given a restricted diet of chow + calcium lactate or chow + calcium cyclamate with and without added fat for 30 weeks

(Mean values with their standard errors for five rats)

\begin{tabular}{|c|c|c|c|c|c|}
\hline \multirow[b]{3}{*}{ Dietary addition } & \multicolumn{3}{|c|}{${ }^{14} \mathrm{CO}_{2}$ expired } & & \\
\hline & \multirow[b]{2}{*}{$\begin{array}{c}\%{ }^{14} \mathrm{C} \\
\text { in glucose dose }\end{array}$} & \multirow{2}{*}{$\begin{array}{c}\text { Relative to } \\
\text { body-wt } \\
\text { (counts } / \mathrm{min} \\
\times 10^{4} \text { per } \mathrm{g} \text { ) }\end{array}$} & \multirow{2}{*}{$\begin{array}{l}\text { Relative to } \\
\text { liver wt } \\
\text { (counts } / \mathrm{min} \\
\times 10^{6} \text { per } \mathrm{g} \text { ) }\end{array}$} & \multicolumn{2}{|c|}{ Liver } \\
\hline & & & & $\begin{array}{l}\text { Glucose } \\
(\mathrm{mg} / \mathrm{g})\end{array}$ & $\begin{array}{c}\text { Glycogen } \\
(\mathrm{mg} / \mathrm{g})\end{array}$ \\
\hline Lactate & $\begin{array}{r}18 \cdot I \\
\pm I * 4\end{array}$ & $\begin{array}{r}2 \cdot 60 \\
\pm 0.20\end{array}$ & $\begin{array}{r}0.88 \\
\pm 0.06\end{array}$ & $\begin{array}{r}0.29 \\
\pm 0.06\end{array}$ & $\begin{array}{r}\text { I } 18 \\
\pm 2 \cdot 7\end{array}$ \\
\hline $3 \%$ Cyclamate & $\begin{array}{r}19.0 \\
\pm 2.0\end{array}$ & $\begin{array}{r}2.93 \\
\pm 0.37\end{array}$ & $\begin{array}{r}1.06 \\
\pm 0.14\end{array}$ & $\begin{array}{r}0.28 \\
\pm 0.02\end{array}$ & $\begin{array}{r}9.8 \\
\pm 1 \cdot 2\end{array}$ \\
\hline $\begin{array}{l}\text { Lactate }+5 \% \text { added } \\
\text { fat }\end{array}$ & $\begin{array}{r}16 \cdot 9 \\
\pm 1 \cdot 7\end{array}$ & $\begin{array}{r}2 \cdot 51 \\
\pm 0.26\end{array}$ & $\begin{array}{r}0.86 \\
\pm 0.07\end{array}$ & $\begin{array}{r}0.29 \\
\pm 0.04\end{array}$ & $\begin{array}{r}14 \cdot 3 \\
\pm I \cdot 8\end{array}$ \\
\hline $\begin{array}{l}3 \% \text { Cyclamate }+5 \% \\
\text { added fat }\end{array}$ & $\begin{array}{r}26 \cdot 6 \\
\pm 2 \cdot 2\end{array}$ & $\begin{array}{r}4 \cdot 10 \\
\pm 0.36\end{array}$ & $\begin{array}{r}177 x \\
\pm 0.17\end{array}$ & $\begin{array}{r}0.26 \\
\pm 0.02\end{array}$ & $\begin{array}{r}10.4 \\
\pm I \cdot 9\end{array}$ \\
\hline
\end{tabular}

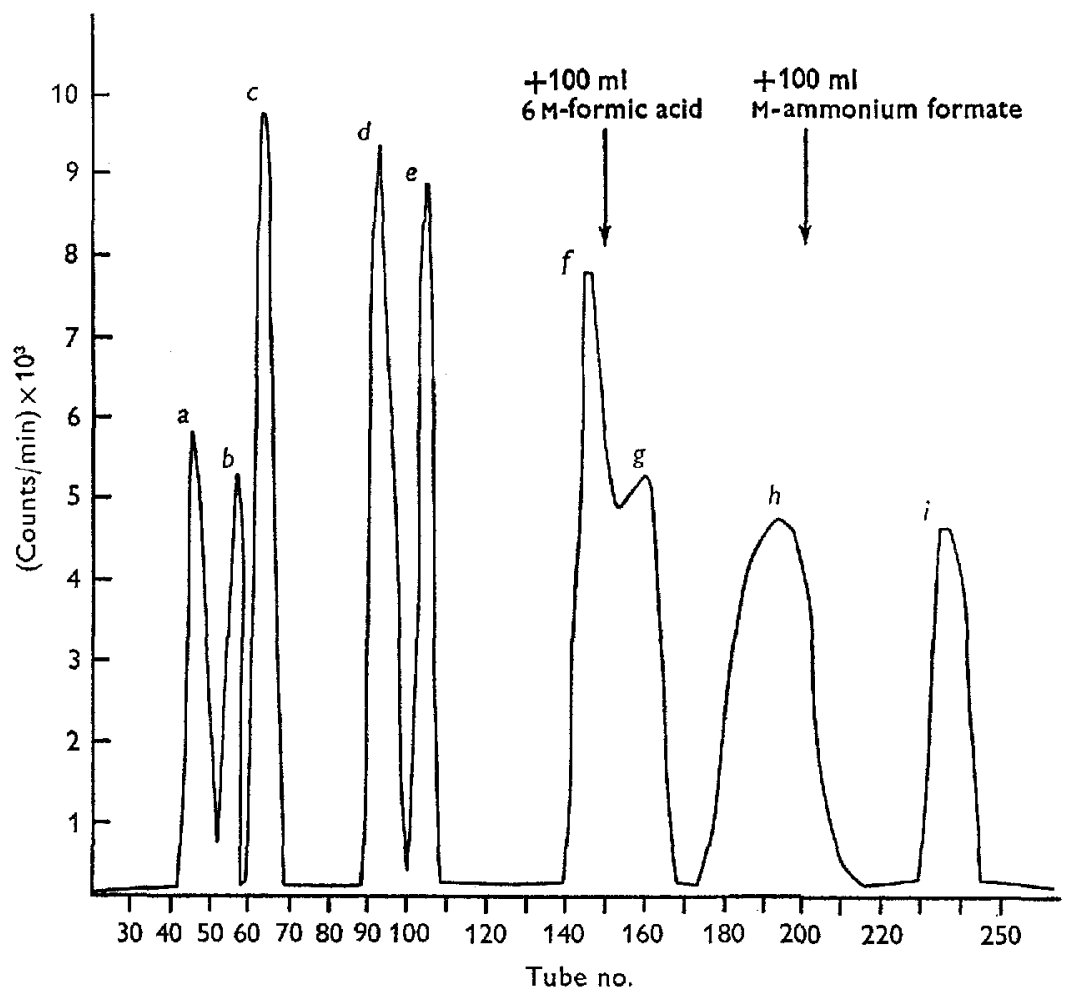

Fig. 2. A radiochromatogram of standard radioactive metabolites eluted from a Dowex-Iformate resin. (a) Glutamic acid, (b) aspartic acid, (c) lactic acid, (d) succinic acid, (e) malicacid, (f) citric acid, $(g)$ glucose-6-phosphate, $(h)$ glycerol-1-phosphate and (i) fructose-1,6diphosphate. 
The concentrations fell within the range of normal values; however, an increase in glutamate and a decrease in liver succinate and lactate were observed in the rats given the fat-supplemented diet plus cyclamate.

Table 6. Concentration ( $\mu$ mollg) of some metabolic intermediates in liver of rats given a restricted diet of chow + calcium lactate or chow + calcium cyclamate with and without added fat for 30 weeks

(All values are means of three determinations from each of two chromatographic separations (two rats))

\begin{tabular}{|c|c|c|c|c|c|c|c|}
\hline Dietary addition & Glutamate & Aspartate & Lactate & Succinate & Malate & Citrate & $\begin{array}{l}\text { Glycerol-I- } \\
\text { phosphate }\end{array}$ \\
\hline Lactate & $I \cdot 06$ & 0.35 & I I $\cdot 34$ & $I \cdot 04$ & 0.59 & 0.054 & $x \cdot 3^{6}$ \\
\hline $3 \%$ Cyclamate & $I \cdot 3 I$ & 0.29 & $9 \cdot 72$ & $1 \cdot 02$ & 0.75 & 0.078 & $1 \cdot 6 I$ \\
\hline $\begin{array}{l}\text { Lactate }+5 \% \\
\text { added fat }\end{array}$ & $1 \cdot 30$ & 0.42 & 13.72 & 0.96 & $0.8 \mathrm{r}$ & 0.068 & $\mathrm{r} \cdot 24$ \\
\hline $\begin{array}{l}3 \% \text { Cyclamate }+ \\
5 \% \text { added fat }\end{array}$ & $\mathbf{r} \cdot 96$ & 0.37 & $6 \cdot 46$ & 0.68 & $0.6 \mathrm{I}$ & 0.066 & I. I9 \\
\hline
\end{tabular}

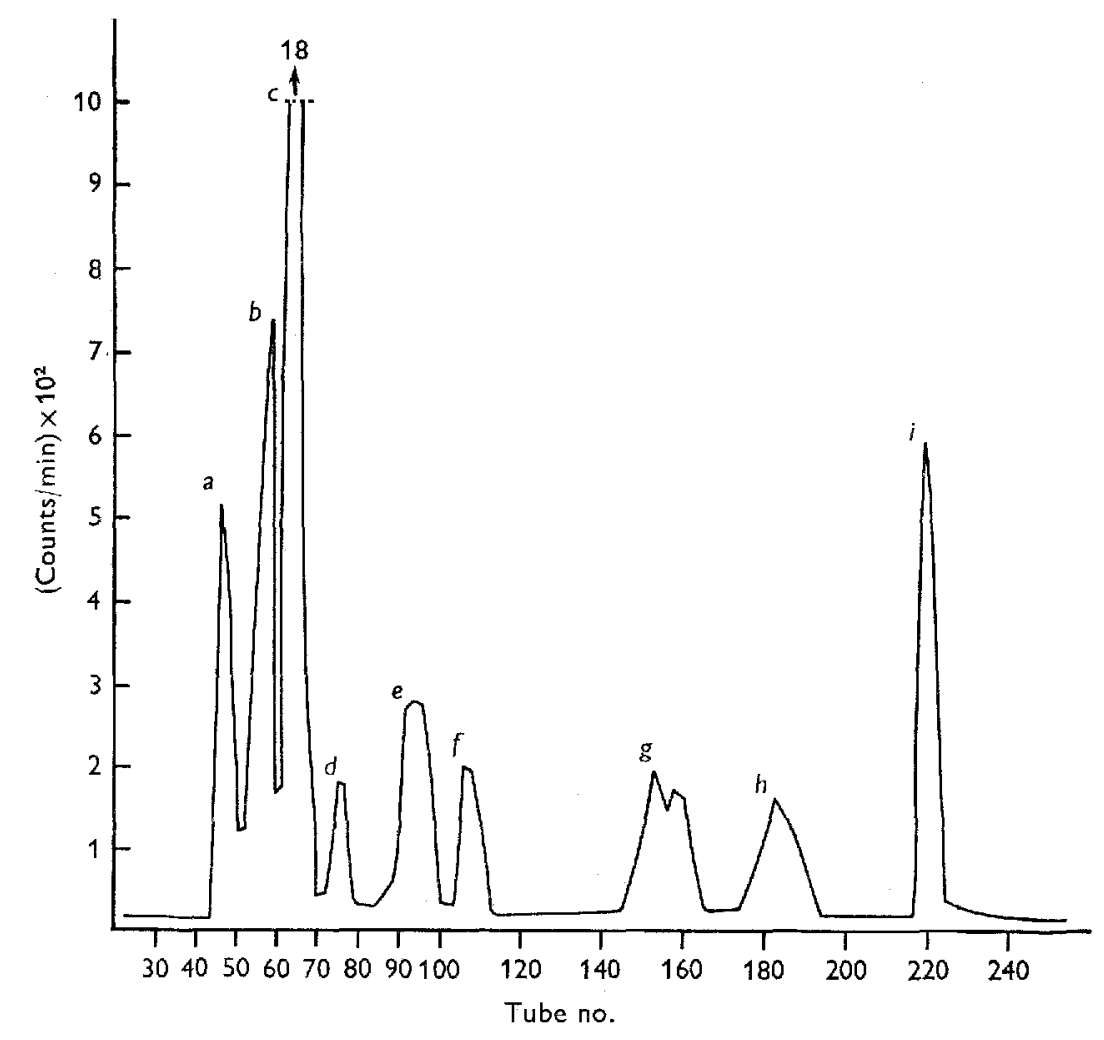

Fig. 3. A radiochromatogram of a liver extract from a rat given a chow diet + fat + cyclamate, eluted from a Dowex-1-formate resin. Compounds isolated, identified and assayed: $(a)$ glutamic acid, $(b)$ aspartic acid, $(c)$ lactic acid, $(d)$ unknown, $(e)$ succinic acid, $(f)$ malic acid, $(g)$ citric acid + glucose-6-phosphate, $(h)$ glycerol-I-phosphate and $(i)$ fructose-1,6-diphosphate. 


\section{DISCUSSION}

Though cyclamates have been considered as pharmacologically inactive, they cause a softening of stools or diarrhoea when administered in high amounts (Fitzhugh et al. I951; Hwang, I966; Schoenberger et al. r953; Taylor et al. I968; Richard, Taylor, O'Brien \& Duescher, 195I). This was clearly demonstrated in eleven groups of rats given commercial chow supplemented with $0-4 \%$ calcium cyclamate for an 8 -week period. Chronic diarrhoea was observed in rats given $\mathrm{I} \%$ cyclamate or more in the diet. Body-weights of rats given diets containing 3 or $4 \%$ cyclamate decreased from control values during the $4^{\text {th }}$ week of feeding and by the 8 th week were $12 \%$ below normal; however, no changes were observed between the groups in liver concentrations of lipid, protein, RNA-P and DNA-P, or in serum concentrations of lipid and protein. The loss of weight appeared to be associated with loss of fluid in diarrhoea. Nees \& Derse (1967) explain the decreased body-weight as an effect of cyclamate either directly on the adrenals or indirectly by way of the pituitary. An increased uptake of iodine accompanied by increased oxygen consumption and respiratory rate indicated a possible disturbance of metabolism. In our studies we were unable to demonstrate any differences in ${ }^{14} \mathrm{CO}_{2}$ excretion after $\left[{ }^{14} \mathrm{C}\right]$ glucose administration to rats whose weight gains were depressed. Indeed, small quantities of cyclamate in the diet $(0.43 \%)$ seem to stimulate appetite and efficiency of food conversion and to be associated with an increase in body-weight (Dalderup \& Visser, 1969).

In order to accentuate any metabolic effects of cyclamate, rats were allowed to grow to maturity on a commercial chow diet supplemented with $5 \%$ fat. These animals did not differ from controls given the chow diet, with the possible exception of slight increases in liver and serum lipid. When cyclamate was added to the fat-supplemented diet and the intake was restricted for a 15 -week period, the rats lost approximately twice as much weight and metabolized $20 \%$ more glucose than the controls given fat plus lactate. No weight loss or significant increase in glucose utilization was observed when cyclamate was added to the normal chow diet. The results indicate that addition of fat to the diet inhibits glucose conversion into $\mathrm{CO}_{2}$, whereas the further addition of cyclamate reverses this process.

The food intake of rats fed on these diets was then restricted at a lower level for an additional I $_{5}$ weeks to establish the relationship between weight loss and glucose oxidation. Weight losses were the same in all groups at the end of the experimental period. Apparently the rats given the diet supplemented with both fat and cyclamate became metabolically adjusted and they lost no additional weight during the second I 5 weeks of restriction. The use of cyclamates in weight-reduction programmes except as substitutes for nutritive sweeteners has already been questioned by other investigators (Dalderup \& Visser, r969; Sabri et al. I969). The livers of the cyclamatefed rats weighed $10 \%$ less than those of controls and were also significantly smaller when compared on a body-weight basis $(P<0.005)$. Serum concentrations of lipid and free cholesterol were decreased in this group, indicating an effect of cyclamate on fat metabolism. The increase of $35 \%$ in ${ }^{14} \mathrm{CO}_{2}$ production from $\left[{ }^{14} \mathrm{C}\right]$ glucose was significant whether calculated on a body-weight or liver-weight basis and indicates a 
higher metabolic rate. This is in agreement with the studies of Nees \& Derse (1967) on whole rats and the findings of Stein, Serrone \& Coulston ( 1967 ) who used isolated liver mitochondria. Glucose and glycogen concentrations of the livers of these rats were unchanged, showing that the differences in ${ }^{14} \mathrm{CO}_{2}$ excretion cannot be attributed to pool size.

Analysis of a number of glycolytic intermediates and glutamate and aspartate isolated from liver indicated no remarkable changes. All values fell within the normal range reported previously by Hoberman \& Prosky $(1967)$. There are indications that cyclamate-fed animals have increased concentrations of glutamate and decreased concentrations of aspartate, lactate and succinate. Since increased concentrations of lactate and succinate have been associated with varying degrees of anaerobiosis (Hoberman, Prosky \& Arfin, 1965; Hoberman \& Prosky, 1967), the high metabolic rate of cyclamate-fed rats would tend to maintain the concentration of these metabolites at a lower level.

The authors thank Mr Theodore S. Bond and Mrs Rosiebell M. Branch for technical assistance and Mrs Holdine Roginski for her help in preparation of the figures.

\section{REFERENCES}

Bergmeyer, H. U. (1965). Methods of Enzymatic Analysis and ed. New York: Academic Press.

Bloor, W. R., Pelkan, K. F. \& Allan, D. M. (1922). J. biol. Chem. 52, rgr.

Bray, G. A. (1960). Analyt. Biochem. 1, 279.

Busch, H., Hurlbert, R. B. \& Potter, Van R. (1952). F. biol. Chem. r96, 717.

Clark, B. \& Porteous, J. W. (1964). Biochem. F. 93, 21 $c$.

Dalderup, L. M. \& Visser, W. (I969). Nature, Lond. 221, 9 I.

Fitzhugh, O. G., Nelson, A. A. \& Frawley, J. P. (1951). F. Am. pharm. Ass. 40, 583 .

Hoberman, H. D. \& Prosky, L. (1967). Biochim. biophys. Acta 148, 392.

Hoberman, H. D., Prosky, L. \& Arfin, H. W. (1965). Fedn Proc. Fedn Am. Socs exp. Biol. $24,229$.

Hwang, K. (1966). Archs int. Pharmacodyn. Ther. 163, 302.

Lowry, O. H., Roberts, N. R., Leiner, K. Y., Wu, M. \& Farr, A. L. (1954). f. biol. Chem. 207, I.

Lowry, O. H., Rosebrough, N. J., Farr, A. L. \& Randall, R. J. (1951). J. biol. Chem. 193, 265.

Miller, J. P., Crawford, L. E. M., Sonders, R. C. \& Cardinal, E. V. (I966). Biochem. biophys. Res. Commun. 25, 153 .

Nees, P. O. \& Derse, P. H. (1965). Nature, Lond. 208, 8 I.

Nees, P. O. \& Derse, P. H. (1967). Nature, Lond. 213, г19і.

Prosky, L., Roberts, B. Jr, O'Dell, R. G. \& Imblum, R. L. (Ig68). Archs Biochem. Biophys. r26, 393. Richard, R. K., Taylor, J. D., O’Brien, J. L. \& Duescher, H. O. (195I). F. Am. pharm. Ass. 40, I. Rubini, M. E. (1969). Am. F. clin. Nutr. 22, 229.

Sabri, M. I., Sharma, S. K. \& Krishna Murti, C. R. (1969). Br. F. Nutr. 23, 505.

Schneider, W. C., Striebich, M. J. \& Hogeboom, G. H. (1956). F. biol. Chem. 222, 969.

Schoenberger, J. A., Rix, D. M., Sakamoto, A., Taylor, J. D. \& Kark, R. M. (1953). Am. F. med. Sci. 225, 55 I.

Seifter, S., Dayton, S., Novic, B. \& Muntwyler, E. (1950). Archs Biochem. 25, I91.

Stein, A. A., Serrone, D. M. \& Coulston, F. (1967). Toxic. appl. Pharmac. 10, 381.

Taylor, J. D., Richards, R. K. \& Davin, J. C. (I95 I). Prac. Soc. exp. Biol. Med. 78, 530.

Taylor, J. D., Richards, R. K., Wiegand, R. G. \& Weinberg, M. S. (r968). Fd Cosmet. Toxic. 6, 3 г 3. 